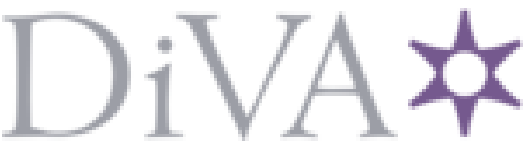

http://www.diva-portal.org

\title{
Postprint
}

This is the accepted version of a paper published in Environmental Communication: $A$ Journal of Nature and Culture. This paper has been peer-reviewed but does not include the final publisher proof-corrections or journal pagination.

Citation for the original published paper (version of record):

Olausson, U. (2017)

"Stop Blaming the Cows!": How Livestock Production is Legitimized in Everyday

Discourse on Facebook.

Environmental Communication: A Journal of Nature and Culture

https://doi.org/10.108o/17524032.2017.1406385

Access to the published version may require subscription.

N.B. When citing this work, cite the original published paper.

Permanent link to this version:

http://urn.kb.se/resolve?urn=urn:nbn:se:hj:diva-38263 
The Version of Record of this manuscript has been published in Environmental Communication 7 Dec 2017. Article https://doi.org/10.1080/17524032.2017.1406385.

\section{“Stop Blaming the Cows!”: How Livestock Production is Legitimized in Everyday Discourse on Facebook}

In 2016, Swedish climate reporting declined in quantity and shifted focus somewhat from climate change as such to the harmful climate impacts of meat consumption. The latter prompted discussions in social media - an increasingly important forum for public debate but infrequently studied in environmental communication research. Despite strong evidence that a meat and dairy based diet is devastating for the environment, meat consumption is increasing, and this qualitative study aims to - through the lens of social representation theory contribute knowledge about how livestock production is legitimized in everyday discourse on Facebook. The article identifies representations that legitimize livestock production through polarization between (1) livestock production and other (environmental) issues, (2) environmentally “good” and "bad” countries, and (3) “reliable” and “unreliable” information. It concludes by discussing the influence of national ideology on the legitimization of livestock production and the potential of social media to counter the post-politicization of environmental issues.

\section{Keywords}

social media; environmental communication; social representation theory; climate change; meat; lay sense-making

\section{Introduction}


When it comes to sustainability issues in general and environmental concerns in particular, Sweden is often described as something of a role model. For instance, in 2016, it was ranked in third place on Yale University’s Environmental Performance Index (Hsu et al., 2016). This inclination towards environmental consciousness was also mirrored in Swedish news media, which reported frequently on the environment - and not least the climate issue - and highlighted environmental responsibility on the international, national, local as well as individual level (Olausson, 2009, 2010). While this is true, the relationship between meat consumption and environmental degradation has played a modest (to say the least) role in news agendas in Sweden, as elsewhere (e.g. Almiron and Zoppeddu, 2015; Benulic, 2016; Neff, Chan, and Smith, 2008). In 2016, however, there seems to have been an interesting turn of events in this regard, and a recent report (Vi-Skogen, 2017) shows that Swedish climate reporting, besides declining quantitatively, shifted its focus somewhat from dealing with climate change as such to focusing on how meat consumption affects the climate.

The media's tendency to increasingly acknowledge the link between meat consumption and climate change clearly has engaged people in everyday life, not least in social media. According to the report, the two most widely shared environmental media items ${ }^{1}$ singled out air travel as a far more serious climate threat than livestock keeping for meat and dairy production, while downplaying the environmental impacts of the latter. Numerous studies, however, have presented convincing evidence that a meat and dairy based diet is harmful in multiple ways for the environment and is a significant contributor to climate change (Cole and McCoskey, 2013; Gerber et al., 2013; Steinfeld et al., 2006).

Nevertheless, the environmental impacts of livestock production are probably among the most difficult to come to terms with, largely due to the increasingly prominent role of meat in 
contemporary lifestyles. In Sweden, where meat consumption is still low compared with Australia and the USA (Benulic, 2016), there was an increase of 37 percent between 1980 and 2014 (Swedish Board of Agriculture, 2015). It is also well known that people do not passively receive information from the media or from expert sources, for instance about meat's impact on the environment; this transmission model of communication has repeatedly been rejected in communication research. Instead, people incorporate such information into the context of their own experiences, worldviews, and identifications, and if it conflicts with their existing beliefs and behaviors, emotional discomfort caused by cognitive dissonance (Festinger, 1957; Kahan, 2006) is likely to arise. There is ample evidence that people negotiate or entirely discard (scientific) information about the climate issue (Olausson, 2011), for instance by denying the environmental benefits of reduced meat consumption - possibly as a strategy for lessening dissonance (Loughnan, Haslam, and Bastian, 2010; Tobler, Visschers, and Siegrist, 2011). However, as noted by Piazza et al. (2015), the precise ways in which livestock production is justified and legitimized by people in everyday life is under-researched. Increased knowledge is needed in order to meet the sustainability challenges ahead, which to a large extent will involve consumer responsibility in the form of reduced consumption of meat and dairy. The responses in social media to the widely shared articles about livestock production, mentioned above, offer an excellent opportunity to empirically investigate this.

It is hardly controversial to claim that the overall media ecology has undergone major shifts in recent years, not least due to the massive expansion of social media such as Facebook and Twitter. Network society (Castells, 2005) has fostered a “participatory culture” of "produsing” and sharing (Jenkins, 2009), and social media are saturated with representations of the environment, which are rapidly circulated among large groups of people, who, in turn, might reinforce, negotiate and oppose the representations as communicated in news feeds, tweets, 
visuals, and videos within and across the various platforms. In short, social media constitute an increasingly important forum for public debate and provide a vast data source for studying both previously inaccessible aspects of social interaction and meaning-making on environmental issues (Williams, McMurray, Kurz, and Lambert, 2014) and emerging ones shaped by the technological affordances of social media. Thus, by turning to social media, the present study adds an important dimension to previous research on laypeople’s representations of the environment in general and climate change in particular, which have mostly relied on survey studies (e.g. Portinga, Spence, Whitmarsh, Capstick, and Pidgeon, 2011) and focus-group studies (Olausson, 2011; Benulic, 2016; Marcu et al., 2015; Wibeck, 2014).

Today, the study of the relationship between Internet in general and the environment is quite well established (e.g. Koteyko, Nerlich, and Hellsten, 2015). Studies have examined, for instance, the negotiation of animal-based diets in the campaigning of environmental advocacy organizations (Freeman, 2010; Laestadius, Neff, Barry, and Frattaroli, 2016), and blogs with a particular focus on climate skepticism (Elgesem, Steskal, and Diakopoulos, 2015; Matthews, 2015; Sharman, 2014). However, when it comes to environmental issues and social media in particular, our knowledge is comparatively limited (Hutchins, 2016; Matthews, 2015; Williams et al., 2014), and has a strong focus on the use of social media in the campaigning of environmental movements (Hestres, 2014; Hutchins, 2016; Katz-Kimchi and Manoswevitch, 2015). The few studies that investigate social media in relation to climate change have concentrated heavily on Twitter, examples being the role of Twitter in shaping the climate debate (Auer, Zhang, and Lee, 2014; Kirilenko and Stepchenkova, 2014), in framing IPCC assessment reports (O’Neill, Williams, Kurz, Wiersma, and Boykoff, 2015; Pearce, Holmberg, Hellsten, and Nerlich 2014), and in creating open forums as well as echo chambers 
for climate discussions (Williams et al., 2015). As suggested by Hutchins (2016), the microblog Twitter is certainly an important addition to the "media ecology mix" (p. 25) in the conduct of environmental politics. However, Twitter to a large extent is also associated with elite discourse, and in order to capture the representations of people in everyday life, the present study turns to discussions on the social networking site Facebook. Thus, the study aims to contribute knowledge about ways in which livestock production is legitimized in everyday discourse on Facebook.

The article has four sections including this introduction. The second section accounts for the analytic framework of social representation theory, and introduces the material studied, which consists of Facebook comments on the two most widely shared articles about the environment in 2016. In the third section, the results are presented. These are thematically structured around the central findings as representations that legitimize livestock production through polarization between (1) livestock production and other (environmental) issues, (2) environmentally "good” and "bad” countries, and (3) "reliable” and “unreliable” information. The concluding section discusses the influence of national ideology on the legitimization of livestock production and the potential of social media to counter the post-politicization of environmental issues.

\section{Analytic Framework, Material and Method}

In order to capture ways in which livestock production is legitimized in everyday discourse on Facebook, the analytic framework of social representation theory (SRT) was used. This was previously deployed in research investigating everyday sense-making of various environmental issues (e.g. Olausson, 2011; Smith and Joffe, 2013; Wibeck, 2014). SRT 
emphasizes collective dimensions of our everyday cognitions of the world that help us organize and familiarize our perceptions (Moscovici, 2000). The relationship between cognition and communication is regarded as a dialectic one; all human communication presupposes social representations at the same time as social representations are maintained, transformed and renewed through communication (Moscovici, 2000). Social representations should thus be seen both as a product, i.e. a collectively shared mental framework for interpreting, explaining and evaluating events and phenomena, and as a process, i.e. the whole set of meaning-making activities within and between various discursive sites (Moscovici, 1988), among which social media must be regarded as pivotal.

SRT stresses that social representations are dynamic discursive-cognitive entities, and draws analytical attention to ways in which certain representations of reality are discursively maintained, how others transform, and how new ones emerge through communication (Marková, 2003). The present study - though fully acknowledging the presence of “polemical” representations (Moscovici, 1988, p. 221) - pays particular attention to representations that naturalize livestock production as something legitimate. As argued by Moscovici (2000), everyday meaning-making to a large extent builds on conventions and collective memory, i.e. “common sense,” which specifically applies to culturally wellestablished practices such as meat and dairy production and consumption.

Broadly speaking, social representations help us organize and familiarize our "ways of world making” (Moscovici, 1988, p. 231), and need to be constituted within familiar domains to take root. These processes of "familiarization” are captured by the SR theoretical concepts of anchoring, by which the unfamiliar, such as the environmental impacts of livestock production, is brought into a well-known sphere of earlier representations, and objectification, 
which occurs when it is materialized into something concrete we may perceive. Anchoring and objectification form the basis for the analytical procedure, described in the next section.

\section{Material and Method}

The material of this study comes from Sweden, a country where environmental issues are comparatively prominent in public discussion and the level of social media use is among the highest in the developed world (Pew Research Center, 2016). Sweden thus constitutes a fruitful case for examining how environmental issues such as livestock production are represented and legitimized in social media.

The material consists of Facebook comments on the two most widely shared media items about the environment during 2016 (Vi-Skogen, 2017). The topical articles - published in the tabloid newspaper Aftonbladet and the magazine Land, and shared on their respective Facebook page - both defended keeping livestock for meat and dairy production and contrasted it with vacation air travel, which was pointed out as the "real” environmental villain. The extensive sharing of the two articles, which explicitly downplay the environmental impacts of livestock production, suggests that this position resonates well with established representations, and they were selected precisely because of their potential to trigger a variety of discursive strategies ${ }^{2}$ to (re)produce legitimizing representations of livestock production (cf. Olausson, 2017a, 2017b). The two articles thus function as a form of stimulus material, as is commonly used in focus-group studies.

\section{Table 1: Analyzed Facebook comments}




\begin{tabular}{|c|c|c|}
\hline Publication & $\begin{array}{l}\text { Aftonbladet }(A B), \text { (online }+ \\
\text { daily tabloid newspaper) }\end{array}$ & $\begin{array}{l}\text { Land (online + weekly } \\
\text { magazine) }^{3}\end{array}$ \\
\hline Article headline & $\begin{array}{l}\text { "You blame my cows - and } \\
\text { then take off to Thailand" }\end{array}$ & $\begin{array}{l}\text { "It's not my cows that are } \\
\text { the problem - but your } \\
\text { flights to Thailand"5 }\end{array}$ \\
\hline Type of article & Op-Ed & Report of the $A B$ Op-Ed \\
\hline $\begin{array}{l}\text { Date of publication on } \\
\text { Facebook }\end{array}$ & 1 Dec 2016 & 3 Jan $2017^{6}$ \\
\hline Number of times shared & 88 & 780 \\
\hline $\begin{array}{l}\text { Number of Facebook } \\
\text { comments }\end{array}$ & $\begin{array}{l}\text { Original comments: } 76 \\
\text { Comments in threads: } 53 \\
\text { Total: } 129\end{array}$ & $\begin{array}{l}\text { Original comments: } 199 \\
\text { Comments in threads: } 318 \\
\text { Total: } 517\end{array}$ \\
\hline
\end{tabular}

The method for analysis is qualitative, designed to capture legitimating representations of livestock production, and builds on the SR theoretical concepts of anchoring and objectification. Moscovici (2000) argues that “material from samples of conversations gives access to the social representations” (p. 62), and Whitmarsh (2009) points out that qualitative methods can generate valuable knowledge about their comprehensiveness and cultural embeddings. The codebook outlined below, which contains a number of analytical concepts connected to anchoring and objectification, was consistently applied to all Facebook comments on the two articles (see Olausson, 2011; Höijer, 2011; Moscovici, 2000). It should be noted, however, that Facebook comments are heterogeneous to say the least; not every comment actually dealt with the topic and many engaged solely in mudslinging at 
commentators with diverging opinions (cf. Koteyko, Jaspal, and Hellsten, 2012). Thus, the codebook was applicable to many but not all comments in the sample.

\section{Anchoring}

- Polarization. One important way of transforming that which is unfamiliar into part of a familiar interpretative framework is to organize the construction of meaning around well-known polarities, such as good/bad, more/less, etc. In what ways do the Facebook commentators legitimize livestock production through polarization?

- Metaphors. Anchoring the unfamiliar within culturally established metaphors may serve legitimating functions. How do the commentators make use of metaphorical language to (re)produce legitimating representations of livestock production?

- Thematic anchoring: Anchoring environmental issues in basic themes, i.e. in preexisting “common sense” ideas such as individualism or national identity, liberates them from anonymity. Thematic anchoring operates "beneath” the other anchoring strategies, constitutes their foundation, and is often implicit and/or unintentional. In what ways do the commentators legitimize and naturalize livestock production through thematic anchoring?

\section{Objectification}

- Ontologization. In the process of materialization, the unfamiliar phenomenon is ascribed concrete characteristics - ontologized - so as to make it comprehensible and tangible. Here, the iconic quality of an imprecise idea or being is in focus and abstract concepts are reproduced in concrete imagery or figures. In what ways do the commentators legitimize livestock production by providing it with concrete characteristics? 
- Emotional objectification. Though not very well elaborated in original SRT, emotions have been emphasized by Höijer (2011) as important components of social representations. In this, imagery with affective content is of particular importance (Olausson, 2010, 2011; Smith and Joffe, 2014). What emotions of relevance for legitimating representations of livestock production are conveyed in the comments?

Because the anchoring and objectification strategies operate at different discursive-cognitive levels (for example thematic anchoring works "beneath the surface,” is often unintentional, and constitutes the basis of other strategies), and considering the rather complex nature of many comments, each comment in the sample could be categorized as containing several strategies of anchoring and objectification. In order to ensure the transparency and systematics of the analytical procedure, i.e. to make visible the connection between analytical concepts, empirical material, and interpretations for the sake of reliability, the operation of the analytical concepts is visible throughout the analysis and interpretations are supported by quotations $^{7}$, typical of the considerably larger body of empirical material (Ekström and Larsson, 2010; Tracy, 2010).

A common validity problem in interview (and survey) studies is that people are likely to express what they think is expected of them, rather than their "real” views on the topic. In relation to environmental issues there are, in all probability, certain ways of expressing oneself that are considered to be more suitable than others in order to appear as a "moral" person in the presence of a researcher. Facebook comments, on the other hand, constitute research data with higher validity because they are unaffected by elements associated with the research process (Olausson, 2011; Regan et al., 2016). 
The three themes that structure the results section were identified as distinguishing features of the material because they are present on both of the Facebook pages analyzed (despite their probably attracting quite different users), and, most importantly, because they have roots in thought-systems of a more general kind, for instance national ideology. In this way, the increase in analytical abstraction entails an increase in (theoretical) generalizability (Danermark, Ekström, Jakobsen, and Karlsson, 2002). Livestock production for meat and dairy consumption should also be understood as an exemplar (Flyvbjerg 2006), i.e. a critical case which illustrates the more general problem of how environmentally harmful phenomena or behaviors are justified in everyday discourse (cf. Höijer, 2008). As noted by Flyvbjerg (2006, p. 219), drawing on Kuhn, “a scientific discipline without a large number of thoroughly executed case studies is a discipline without systematic production of exemplars, and a discipline without exemplars is an ineffective one.”

The analytical focus on legitimating representations does not preclude the existence of other and more polemical representations in the studied material. On the contrary, the Facebook discussions studied here encompass plenty of controversy and seem to create open forums rather than echo chambers (Williams et al., 2015). Even though this controversy is not the main focus of the present study, polemical representations are included in the analysis, provided that they shed light on the meaning-making processes that constitute legitimating representations (cf. Olausson, 2017a, 2017b).

When it comes to qualitative analysis of social media, there are always ethical issues to take into consideration such as whether or not to reveal commentators' identities. Since the analyzed comments are published in a public forum, and are easily searchable on Facebook, it is impossible to guarantee full anonymity. Even so, when reporting the Facebook comments 
in the next section, the factual names of the commentators are replaced with alias (cf.

Olausson, 2017a, 2017b).

\section{Results}

This section is thematically structured around the central findings, namely representations that legitimize livestock production through polarization between (1) livestock production and other (environmental) issues, (2) environmentally "good” and "bad" countries, and (3) “reliable” and "unreliable” information.

\section{Polarization between Livestock Production and Other (Environmental) Issues}

\section{Livestock Production vs. Air Travel}

Obviously, one way of legitimizing livestock production is to pick up on the original articles' representation of air travel, particularly related to vacation trips, as being the "real” polluter, as opposed to livestock production. In the quotations below the environmental impacts of air travel are ontologized, i.e. provided with tangible contours, in links to various charts that show the number of planes in the air at a given moment. Of course, the reasoning goes, compared with all these aircraft simultaneously trafficking global air space, the environmental impacts of livestock production must be trivial.

\footnotetext{
A.A:

Have a look at this link, after that I doubt anyone will need to be upset about a few cows. https://sv.flightaware.com/live/. 3 Jan. 14.12.

l...l

Land

/.../

B.B:

“M.E, 29 December 2016, 00:24. This many planes are in the air over the USA at this moment. Did someone say we have to stop eating meat to bring down CO2 levels ;).”
} 
https://www.facebook.com/photo.php?fbid=10208003277706637\&set=a.1712399 216679.82888.1439110350\&type=3\&. 3 Jan. 13.58.

/.../

Land

In all probability, the problems with air travel are much easier to ontologize than the environmental impacts of livestock production, which are well-nigh impossible to reproduce in such an iconic fashion. However, polarization between livestock production and air travel is also carried out without the support of such tangible "evidence.” In the quotations below it is more a matter of anchoring the issue in commonsensical representations of what is conceivable at all; that it is entirely self-evident (so the reasoning goes) that aircraft bring more harm to the environment than cows.

C.C:

How can anyone possibly believe that cows are more dangerous for the environment than aircraft and other motor vehicles? It’s just ridiculous! 1 Dec. 17.06.

$A B$

\section{D.D:}

Agree one hundred percent, stop blaming the cows, ${ }^{8}$ it's crazy. Do something about all the other emissions! /.../ 1 Dec. 14.37.

l.../

$A B$

This naturalized, commonsensical representation - that livestock production more or less by definition causes less environmental harm than air travel - is in turn thematically anchored in a taken-for-granted representation of "naturalness," i.e., that cows are a creation of nature and are necessary for the very survival of humans. This underpins the polarization between livestock and air travel, with the latter instead being represented as human-made and entirely superfluous.

\section{E.E:}

Can't understand people who defend air travel against cows in pastures, which is more natural? /.../ 5 Jan. 18:53.

Land 


\section{F.F :}

We need " but not flights all over the place /.../! 3 Jan. 15:01.

Land

Another element in the polarization between cows and air travel is the ontologization of livestock's consequences, which does not take the form of images of environmental devastation, but rather various enjoyable products such as meat and milk, as shown in the quotations below. The issue is also emotionally objectified in the representation of cows as “cute” and "wonderful” along with emojis such as hearts. This assigns both tangible and attractive contours to livestock production.

\section{G.G:}

Let the cows fart for chrissake... it's never killed anyone... but plane crashes... uh oh...

Both the meat and the milk are delicious and cows are sooo cute 3 Jan. 13.56 /.../

Land

\section{H.H:}

Long live these wonderful animals... who among other things give me my daily ration of COLD MILK. Hugs. 4 Jan 07.40.

Land

These findings support the conclusion of Piazza et al. (2015) who, drawing on Joy (2010), found evidence of the "4Ns," i.e. that meat-eating is justified by laypeople as natural, normal, and necessary (i.e. that humans naturally crave meat), as well as nice (i.e. that eating meat is enjoyable). The present study also indicates that the emotional pleasure deriving from the sheer presence of these animals is another element that could be added to the "nice" category.

Additionally, the metaphor of "the open landscape" helps anchor the representation of livestock production - unlike air travel - as something natural, necessary, and nice. When used as a legitimating metaphor for livestock production, the open landscape is a potent tool, 
since this nature ideal is firmly culturally established in Sweden, with manifold popular expressions, the most obvious example being the song "Open Landscapes”" ${ }^{9}$ from 1982. This tune, which is still very popular, was even once nominated to be the country's unofficial national anthem. The open landscape metaphor thus resonates well with firmly rooted notions about typical Swedish attributes and nature values.

\section{I.I:}

We need the cows more than planes. Up with open landscapes.!! 5 Jan. 13.55. Land

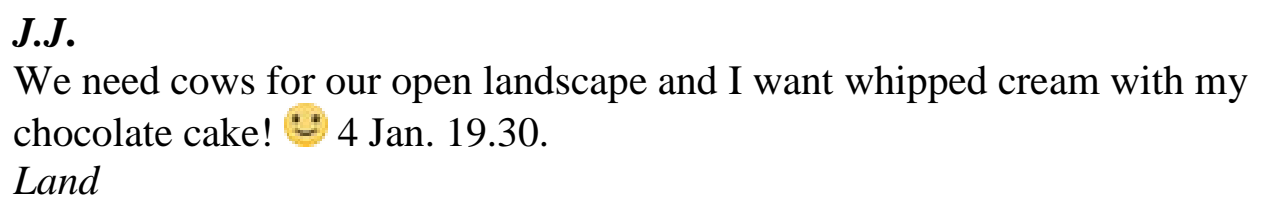

To promote biological diversity, sustaining and developing natural open grazing areas is an explicit goal of Swedish environmental policy (Swedish Board of Agriculture, 2013). However, the Facebook comments are largely disconnected from this aspect of the open landscape, and the metaphor is instead deployed to legitimize livestock production in general.

\section{Livestock Production vs. Other Issues}

The view that environmental problems should be solved in some kind of order of perceived severity is also evident when the commentators represent livestock production as a minor problem compared, not only with air travel, but with a number of other (environmental) issues. Calling attention to the environmental impacts of livestock production and demanding reduced meat consumption would be to "strain a gnat and swallow a camel" as expressed by the commentator K.K. (Land, 3 Jan. 20:14). The polarization between livestock and other issues is visible in the quotations below, where the environmental impacts of livestock production are ontologized (as well as ridiculed and dismissed) as "cow farts.” 


\section{L.L:}

We might as well add fireworks to the list of evil doers when it comes to environmental destruction, so leave the cows alone or anyone else who passes a little gas!! 3 Jan. 15:30.

Land

\section{M.M:}

It's humans who are destroying Mother Earth with atomic weapons tests in the ground, sea and space. ALL the waste we leave behind. So what are cow farts compared to that????? /.../ 3 Jan. 14.04.

/.../

Land

Furthermore, underlying the polarizing strategy, there is a distinct thematic anchoring of livestock production in a representation which is perhaps best described as characterized by conspiracy thinking. In a study of how laypeople make sense of the health risks of meat consumption, Regan et al. (2014) identified a belief that the issue had been pushed into public attention because of the underlying agenda of particular stakeholders. In a similar fashion, the present analysis detects a suspicion that there is a hidden agenda in play working to prevent other, presumably more serious, environmental hazards from coming to public attention.

\footnotetext{
N.N:

/.../ What percentage of emissions do you think cows are responsible for? Typical example of deflecting attention away from the main problem /.../ Do you think the automotive lobby might be behind it? 1 Dec. 09.00.

$A B$
}

This example of conspiracy thinking implies that livestock production has deliberately been made the focus of public debate for the sole purpose of obscuring more pressing environmental issues, which for various reasons are considered too sensitive to address. This assumption is evident in the quotations below in statements such as "No one talks about...", often combined with emotional expressions of frustration and even contempt as in the statement "blaming cows only shows how goddamn naive you are."

\section{l.../}


O.O:

That none of you mention the gigantic container ships that continuously crisscross our oceans. Which run on extremely low-quality fuel. According to a recent

educational program they account for more harm than all the vehicles in the world combined. Blaming cows only shows how goddamn naive you are.” 5 Jan. 17.27. /.../

Land

\section{P.P:}

No one talks about the environmental impacts caused by the wars that are going on in different places. Who cares about that? At least we need to start at the right end of the problem! Not with some poor cows in Sweden. Dumb, dumber, dumbest! 5 Jan. 14.39.

Land

The studied material also contains ample evidence of attempts to negotiate the representation that lends legitimacy to livestock production by polarizing it against other (environmental) concerns. However, as illustrated by the exchange below, even when the original comments in a particular thread attempt to create a bridge between the polarities, the anchoring strategy of polarization prevails and livestock production is legitimized on the basis of the assumption that environmental problems should be solved in order of perceived severity.

\section{Q.Q:}

Meat production and air travel both need to be reduced. The one doesn't exclude the other. 3 Jan. 13.54.

\section{R.R:}

Thank you. My thoughts exactly. 3 Jan. 15.11.

\section{S.S:}

That right, but it ought to be smartest to start with the largest polluters instead of the small ones. It's getting a bit urgent. 3 Jan. 19.17.

l.../

Land

In sum, through polarization, livestock production is legitimized when assessed as much less of an environmental threat than other issues. As long as the "real” environmental dangers are shielded from scrutiny and are not properly dealt with, so the argument goes, there is no point in changing anything about (Swedish) livestock keeping for meat and dairy production. 


\section{Polarization between Environmentally “Good" and "Bad” Countries}

In the Facebook comments, a polarization is apparent between those countries that are considered to behave in an environmentally friendly manner, in this case Sweden, and those that do not, i.e. most of the rest of the world. Previous studies on the media's reporting on climate change have identified the commonsensical representation of national identity as a prominent anchoring strategy along with a discursive struggle regarding the distribution of responsibility for mitigating climate change among countries (Olausson, 2009, 2010; Schmidt and Schäfer, 2015). The same seems to be the case when representations legitimating livestock production are (re)produced among ordinary people; (Swedish) livestock production is legitimized, since there is no point in "us" improving "our” environmental behavior before the rest of the world does. This is shown in the quotations below, which suggest that we should feel good about “our” meat industry, and what is needed is for us to "support Swedish farmers.”

/.../

T.T:

/.../ When it comes to environmental impact, the cows are a drop of piss in the Mississippi compared to Asian industry and the oil industry. Get their emissions under control and the impact of cows will be negligible. It's pretty frightening how far the vegan lobby can reach /.../ Be happy about our Swedish meat industry. Sure, if some people want to be vegetarians, be my guest. But let the rest of us eat good Swedish meat! 4 Jan. 13:31.

Land

\section{U.U:}

Reduce imports of foreign meat. If there's something that's an environmental problem it's Irish (salmonella) and Brazilian meat (transported from the other side of the planet). Support Swedish farmers. 3 Jan. 18:50

Land

Above it was shown how livestock production is legitimized through its anchoring in conspiracy thinking - that the issue has deliberately but undeservedly been pushed into public 
awareness in order to shield other and more serious issues from scrutiny. This thematic anchoring strategy is detectable also in relation to polarization between "good" and "bad" countries. The first quotation below describes an alleged "witch hunt” on Swedish farmers, and in the second quotation the "state" is suspected of wanting to eliminate this occupational group.

\section{V.V:}

ENOUGH NONSENSE! Allow the few farmers remaining in Sweden to give us locally produced food without being classed as evil polluters! /.../ Because how much SWEDISH beef do we actually eat? /.../ Like and share this so we can end this witch hunt against poor Swedish farmers. 2 Dec. 19.14.

$A B$

\section{$W . W:$}

It seems as if the state doesn't want there to be any Swedish farmers at all! In that case we'll have to import milk and meat instead, and that doesn't sound all that climate smart either, does it....? But to hell with it.... then we'll be able to beat our chests because at least SWEDEN doesn't contribute greenhouse gases from agriculture! Looks nice in the statistics! 5 Jan. 18.05.

Land

The studied material also includes polemical representations of livestock production that challenge the national anchoring; the commentator $X . X$., in the exchange below, provides an example of this. However, as demonstrated by the subsequent responses, the thematic anchoring in national identity - livestock production here being metaphorically anchored as part of the cultural heritage - returns in full force with arguments about an active campaign against Swedish farming and the inappropriateness of contextualizing Swedish agriculture in a global context. Emotional objectification in frustration and contempt is evident, for instance, when referring to the environmental movement as "nut jobs" and "environmental Talibans." As long as other countries exhibit worse behavior regarding livestock production, it is entirely unfair to blame Swedish farmers, the argument goes.

\section{X.X:}


/.../ This problem isn't illustrated by Sweden’s idyllic small-scale [agriculture] /.../ Many branches contribute to climate problems; everyone must do their share to deal with them. 1 Dec. 09.27.

Y.Y:

Well, make sure you try to get rid of the large-scale Brazilian livestock industry then, and don't bring our fine Swedish agriculture and heritage into it? Media and the nutjob environmental Talibans are actively threatening Swedish agriculture and forestry. At the same times Swedes have an enormous climate footprint from air travel, but that isn't questioned with campaigns and lobbying. 1 Dec. 09.31.

$X . X$ :

You know how many campaigns there are just to save the rainforest? The point is that this is a global problem that affects us all. Sweden also has to take responsibility for our part in it. /.../. 1 Dec. 09.46.

Y.Y:

X.X., an active campaign is underway against Swedish forestry and agriculture. /.../ This is because the environmental movement views Swedish agriculture and forestry in a global perspective, which is wrong! Compare the figures by country, and work to improve countries that are near the bottom in an international comparison! /.../1 Dec. 09.53.

/.../

$A B$

The thread quoted below departs from the representation of Swedish "goodness," which in this case legitimizes both livestock production and air travel, along with the conclusion that as long as other countries are worse, “we” do not have to improve "our” lifestyle. Polemical representations, similar to those exemplified above, are also injected by commentators $A . B$. and B.B.

Z.Z:

I love meat, especially barbecued, and enjoy traveling to Thailand. Don't see the problem as having to do with Sweden or our way of life, as we manage the climate well. Look at Asia/Africa/America instead....if they reduce their emissions by $5-10 \%$ we'll have come a long way! /.../ है है 3 Jan. 21.32.

A.B:

If everyone on Earth lived like an average Swede we would need almost four planets to maintain the Swedish lifestyle. So your claim is simply not correct. /.../ 4 Jan. 01.25 .

\section{Z.Z:}

Even so, the problem isn't we Swedes......when other countries catch up to Sweden maybe. Then we can do more. Right now, I eat meat and fly without limit. Even drive some. 4 Jan. 01.29.

/.../

B.B: 
Sorry R., but that's an attitude that too many people have, and it's horribly egotistical and ignorant. 5 Jan. 12:33.

\section{Z.Z:}

"Sigh" we live in Sweden....less than 10 million inhabitants. There are fewer of us than the population of London....put your effort where it will do the most good rather than pushing down us Swedes who probably have the "cleanest" lifestyle in the whole world. /.../ It won't help unless the remaining 6.99 billion people do something. Try to influence people outside of Sweden instead. /.../ 5 Jan. 12:57. Land

As it seems, attempts to bridge the polarization between countries in the quotation above are resisted, similar to what happened with the attempts to bridge the polarization between environmental issues. In this process, the commonsensical representation of national identity constitutes an important anchoring foundation.

\section{Polarization between Reliable and Unreliable Information}

In agreement with the findings of Sharman (2014) in her study of climate skepticism in blogs, the present study shows that science, together with negotiations about (un)reliable information, are integral parts of people’s discussions about livestock production on Facebook. In the quotation below, C.B. ontologizes (and thereby, dismisses) the environmental impacts of livestock production in (scientific) information, while simultaneously criticizing Swedish media for being ignorant about nature.

\section{C.B:}

Sure, grass makes cows fart. and the methane is later oxidized in the atmosphere into $\mathrm{CO} 2$ and water. The alternative without cows is that the same grass rots and turns into $\mathrm{CO} 2$ and water in the atmosphere. Swedish media and journalists have zero idea how nature works in general, and like children can only focus on a little piece of nature at a time, such as a cow's anus. 1 Dec. 15.47.

$A B$

Apparently, commentators struggle quite a bit to ontologize livestock production’s environmental consequences in reliable information and figures of various kinds, and the analysis shows the difficulty of assessing sources and navigating among, discriminating and 
making comparisons between the plethora of scientific results and other types of information.

The quotation below, which serves as an illustration of this dilemma, starts with commentator

D.B., who delegitimizes livestock production by pointing to certain information about its

negative impacts. E.B., in turn, responds by dismissing this information, accusing D.B. of

lacking knowledge and referring instead to a blog. At a later stage of the discussion, which at

that point involves several commentators, D.B. discards the information put forward by E.B.,

labeling it “opinions,” and points instead to "accepted facts.”

D.B:

A "biased" dairy farmer who argues for milk and her exploitation of cows by smearing something else. Two wrongs don't make a right. Also, she only talks about methane, which is one of the problems, but avoids mentioning the energy inefficiency of producing meat and milk. The transports that it involves. The incredible amounts of water that are needed, etc., etc.... /.../.1 Dec. 14.24. /.../

E.B:

The studies about the unbelievable water consumption are so completely wrong that they are out of this world. But once incorrect information has gone viral it becomes truth. Find out what's correct next time. 1 Dec. 21.41.

/.../

D.B:

/.../ Well it's not about opinions but about accepted facts. The UN agriculture organization, WHO, the Swedish Environmental Protection Agency and other "viral” sources. /.../ 2 Dec. 09.23.

E.B:

D.B. look at the following blog article which pretty easily pokes a hole in your water footprint balloon http://blogg.land.se/.../kottproduktionens.../ 2 Dec. 11.46. /.../

D.B:

E., So your source is a blog by a meat producing farmer rather than the UN, the Environmental Protection Agency, etc. 2 Dec. 12.29.

D.B. then drops out of the discussion but E.B. continues the thread by anchoring the issue of livestock production thematically in national identity when defending "Swedish farmers" and acknowledging “reality” instead of "fact.”

\section{E.B:}

The problem with your reasoning J.V. is that you see Swedish farmers as evil polluters while I see them as heroes who work pretty much around the clock, all year round, to provide the rest of us with food. They deserve all the appreciation 
we can give them, and definitely don't deserve to be pulled through the dirt. 2 Dec. 20.55.

/.../

\section{E.B:}

I think you ought to contact a farmer and ask if you can help out for a few weeks to see what their lives are like and how it works in reality instead of in "fact." 2 Dec 21:59.

$A B$

The quotations below also demonstrate the commentators' ambition to ontologize the issue of livestock production in (scientific) information, while remaining critical of sources and attempting to discriminate between those that are more or less reliable. Commentator F.B. clearly aspires to do so, but what ultimately seems to matter even to this commentator is the opportunity to thematically anchor the issue in the representation of national belonging; to simply choose to believe in the scientists who allegedly say that Swedish cows are not a cause of climate change.

\section{G.B:}

I don't know which is more embarrassing, the low level of knowledge revealed in some of the comments or the fact that Aftonbladet chose to publish the article. Methane gas has between 20 and 35 times greater environmental impact that carbon dioxide, kilo by kilo. The debate article is a partisan opinion piece. /.../ https://www.google.co.uk/.../sve.../sida/amp/article/3203049 1 Dec. 17.49.

\section{F.B:}

And how do you know there's any truth in the article that you link to? 1 Dec. 17.49.

\section{G.B:}

Well, my dear F. I'm not a climate scientist myself so I simply have to trust that Science, one of the largest scientific journals in the world, has a system for ensuring that the research they publish is scientifically supported. 1 Dec. 17.54.

\section{F.B:}

Well, my dear G. In that case I'll listen to the researchers who say that Swedish cow farts aren't the cause of climate change and assume they have no reason to lie. $1 \mathrm{Dec}$. 19.44 .

/.../

$A B$ 
Polarization between reliable and unreliable information might thus not only question livestock production, but to a significant extent also lend it legitimacy, particularly with the aid of the national anchoring mechanism.

\section{Concluding Remarks}

It is an integral part of human sociality to legitimize one's behavior, especially when it comes under scrutiny, in order to maintain one's self-image as a moral person and thereby reduce cognitive dissonance (Piazza et al., 2015). The analysis presented here has demonstrated significant tendencies toward polarization in the ways in which people (re)produce legitimizing representations of livestock production for meat and dairy consumption. Livestock production is contrasted with other (environmental) issues, Sweden is contrasted with other countries, and various types of information from certain sources are contrasted with other types of information from other sources. In this, a number of discursive strategies are deployed, such as culturally well-established metaphors and emotionally charged arguments, all of which are brought into use for the purpose of pushing livestock production down (or off) the list of urgent environmental issues, thereby assigning it legitimacy. These insights into what discursive strategies of anchoring and objectification people use to legitimize livestock production might for instance prove useful to ENGOs in their campaigning activities.

In particular, it seems as if the commonsensical, taken-for-granted theme of national identity - or in other words, national ideology - serves as a foundation for the legitimization processes; it permeates all three modes of polarization identified in the study. As noted by Cooper, Green, Burningham, Evans, and Jackson (2012) in their exploration of online 
discussions, categorizations of social identity are important building blocks for making arguments about sustainability and consumption, and sustainability issues are often translated into issues of social identity for polemical purposes. This is also evident in the present study, which has demonstrated the prominent role of national identity in the creation of arguments in favor of keeping livestock for meat and dairy production.

It seems reasonable to suggest that the thematic anchoring in national ideology is also a key explanation for the suspicion, identified in the analysis, of some kind of a hidden agenda, where Swedish livestock production is represented as the innocent target of a conspiracy by powerful actors to conceal more harmful practices. By doing so, they would also be threatening Swedish traditions (as livestock production is allegedly a vital part of Sweden’s cultural heritage), lifestyle and nature values; and perhaps even Swedish national identity as a whole. If this line of interpretation is correct, legitimating representations of livestock production intermingle with more general populist discourses about other "threats” (primarily immigration) to Swedish identity and culture, which an (urban) “elite” of (left-wing) politicians, intellectuals and the news media are believed deliberately to be concealing. Based on a study of advertisements, Rogers (2008) suggests that meat consumption is constructed as a response to perceived threats to hegemonic masculine identity posed by the environmental movement. It could well be the case that something similar occurs with perceived threats to hegemonic national identity. This, however, is a question that requires further theoretical and empirical attention.

Finally, as proposed by Cooper et al. (2012), the online forum is a naturally occurring discursive space in which diverse representations might come forth. Social media logic, for instance, allows for many-to-many communication between participants unknown to each 
other. In this sense, social media have the potential to serve as a "discursive bridge" (Olausson, 2007) between people with diverging opinions, life situations and experiences, thereby possibly countering the post-political condition of climate change (Berglez and Olausson, 2014). The post-politicization of the public sphere is a general feature of late modern society, and refers to the abolishment of conflicts, disputes, and disagreements, i.e. the agonistic elements which, according to Mouffe (2005), are constitutive of a wellfunctioning democratic order. According to several scholars (e.g. Maeseele and Raeijmaekers, 2017; Swyngedouw, 2010), environmental discourses in general, and climate change discourse in particular, have entered the post-political stage through a consensual public discourse, which prevents a politics revolving around new visions of the socio-environmental future from emerging. The present study has provided some indications that the affordances of social media actually help disagreements based on social identities to surface discursively. The question to be left for future environmental communication research is to what extent, in what shapes, and with what (post)-political consequences - if any, these disagreements arise.

\section{References}

Almiron, N. and Zoppeddu, M. (2015) Eating meat and climate change: The media blind spot - A study of Spanish and Italian Press coverage. Environmental Communication, 9(3), $307-325$.

Auer, M. R., Zhang, Y., and Lee, P. (2014) The potential of microblogs for the study of public perceptions of climate change. WIREs Climate Change, 5(3), 291-296.

Benulic, K-S. (2016) A beef with meat - Media and audience framings of environmentally unsustainable production and consumption (Unpublished doctoral dissertation). Stockholm: Södertörn University. 
Berglez, P. and Olausson, U. (2014) The post-political condition of climate change: An ideology approach. Capitalism Nature Socialism, 25(1), 54-71.

Carvalho, A. (2005) Representing the politics of the greenhouse effect: Discursive strategies in the British media. Critical Discourse Studies, 2(1), 1-29.

Castells, M. (2005) The rise of the network society: The information age: Economy, society and culture. London: Wiley.

Cole, J. R. and McCoskey, S. (2013) Does global meat consumption follow an environmental Kuznets curve? Sustainability: Science, Practice and Policy, 9(2), 26-36.

Cooper. G., Green, N., Burningham, K., Evans, D., and Jackson, T. (2012) Unravelling the threads: Discourses of sustainability and consumption in an online forum. Environmental Communication, 6(1), 101-118.

Danermark, B., Ekström, M., Jakobsen, L., and Karlsson, J. C. (2002). Explaining society: Critical realism in the social sciences. New York: Routledge.

Ekström, M., and Larsson, L. (2010). Inledning (Introduction). In M. Ekström and L. Larsson (Eds), Metoder i kommunikationsvetenskap (Methods in Communication Studies) (pp. 13 25). Lund: Studentlitteratur.

Elgestam, D., Steskal, L., and Diakopoulos, N. (2015) Structure and content of the discourse on climate change in the blogosphere: The big picture. Environmental Communication, 9(2), 169-188.

Festinger, L. (1957) A theory of cognitive dissonance. Stanford, CA: Stanford University Press.

Flyvbjerg, B. (2006). Five misunderstandings about case-study research. Qualitative Inquiry, 12(2), 219-245.

Freeman, C. P. (2010) Meat's place on the campaign menu: How US environmental discourse negotiates vegetarianism. Environmental Communication, 4(3), 255-276. 
Gerber, P. J., Steinfeld, H., Henderson, B., Mottet, A., Opio, C., Dijkman, J., ... Tempio, G. (2013) Tackling climate change through livestock - A global assessment of emissions and mitigation opportunities. Rome: Food and Agriculture Organization of the United Nations.

Hestres, L. E. (2014) Preaching to the choir: Internet-mediated advocacy, issue public mobilization, and climate change. New Media \& Society, 16, 323-339.

Hsu, A. et al. (2016) 2016 Environmental performance index (Retrieved from http://epi.yale.edu). New Haven, CT: Yale University.

Hutchins, B. (2016) The many modalities of social networking: The role of Twitter in green politics. Environmental Communication, 10(1), 25-42.

Höijer, B. (2008). Ontological assumptions and generalizations in qualitative (audience) research. European Journal of Communication, 23(3), 275-294.

Höijer, B. (2011) Social representation theory: A new theory for media research. Nordicom Review, 32(2), 3-16.

Jenkins, H. (2009) Confronting the challenges of participatory culture. Cambridge: The MIT Press.

Joy, M. (2010) Why we love dogs, eat pigs, and wear cows: An introduction to carnism. San Francisco, CA: Routledge.

Kahan, D. M. (2006) Cultural cognition and public policy. Faculty Scholarship Series. Paper 103. Available at http://digitalcommons.law.yale.edu/fss_papers/103.

Katz-Kimchi, M. and Manosevitch, I. (2015) Mobilizing Facebook users against Facebook’s energy policy: The case of Greenpeace unfriend coal campaign. Environmental Communication, 9(2), 248-267.

Kirilenko, A. P. and Stepchenkova, S. O. (2014) Public microblogging on climate change: One year of Twitter worldwide. Global Environmental Change, 26, 171-182. 
Koteyko, N., Jaspal, R., and Hellsten, I. (2012) Climate change and “Climategate” in online reader comments: A mixed methods study. The Geographical Journal, 179(1), 74-86.

Koteyko, N., Nerlich, B., and Hellsten, I. (2015) Climate change communication and the Internet: Challenges and opportunities for research. Environmental Communication, 9(2), $149-152$.

Laestadius, L. I., Neff, R. A., Barry, C. L., and Frattaroli, S. (2016) No meat, less meat, or better meat: Understanding NGO messaging choices intended to alter meat consumption in light of climate change. Environmental Communication, 10(1), 84-103.

Loughnan, S., Haslam, N., and Bastian, B. (2010) The role of meat consumption in the denial of moral status and mind to meat animals. Appetite 55: 156-159.

Maeseele, P. and Raeijmaekers, D. (2017) Journalism and democracy: Towards a sustainable future. In P. Berglez, U. Olausson, and M. Ots (Eds), What is sustainable journalism? Integrating the environmental, social, and economic challenges of journalism (pp. 116134). New York: Peter Lang.

Marcu, A., Gaspar, R., Rutsaert, P., Seibt, B., Fletcher, D., Verbeke, W., and Barnett, J. (2015) Analogies, metaphors, and wondering about the future: Lay sense-making around synthetic meat. Public Understanding of Science, 24(5), 547-562.

Matthews, P. (2015) Why are people skeptical about climate change? Some insights from blog comments. Environmental Communication, 9(2), 153-168.

Marková, I. (2003) Dialogicality and social representations: The dynamics of mind. Cambridge: Cambridge University Press.

Moscovici, S. (1988) Notes towards a description of social representations. European Journal of Social Psychology, 18, 211-250.

Moscovici, S. (2000) Social representations: explorations in social psychology. Cambridge: Polity Press. 
Neff, R. A., Chan, I. L., and Smith, K. S. (2008) Yesterday’s dinner, today’s weather, tomorrow's news? US newspaper coverage of food system contributions to climate change. Public Health Nutrition, 12, 1006-1014.

Olausson, U. (2007). The ideological horizons of citizenship: National media as discursive bridge. In B. Höijer (Ed.), Ideological horizons in media and citizens discourses: Theoretical and methodological approaches (pp. 51-73). Gothenburg: Nordicom.

Olausson, U. (2009) Global warming - global responsibility? Media frames of collective action and scientific certainty. Public Understanding of Science, 18(4), 421-436.

Olausson, U. (2010) Towards a European identity? The news media and the case of climate change. European Journal of Communication, 25(2), 138-152.

Olausson, U. (2011) “We're the ones to blame”: Citizens’ representations of climate change and the role of the media. Environmental Communication, 5(3), 281-299.

Olausson, U. (2017a) The reinvented journalist: The discursive construction of journalistic identity on Twitter. Digital Journalism, 5(1), 61-81.

Olausson, U. (2017b) The celebrified journalist: Journalistic self-promotion and branding in celebrity constructions on Twitter. Journalism Studies. Published online 2 Aug.

O’Neill, S., Williams, H. T. P., Kurz, T., Wiersma, B., and Boykoff, M. (2015) Dominant frames in legacy and social media coverage of the IPCC Fifth assessment report. Nature Climate Change, 5.

Pearce, W., Holmberg, K., Hellsten, I., and Nerlich, B. (2014) Climate change on Twitter: Topics, communities and conversations about the 2013 IPCC Working group 1 report. PLOS ONE 9(4): e94785. https://doi.org/10.1371/journal.pone.0094785.

Pew Research Center (2016). Spring 2016 Global Attitudes Survey. Available at http://www.pewresearch.org/fact-tank/2017/04/20/not-everyone-in-advanced-economiesis-using-social-media/, retrieved 18 September 2017. 
Piazza, J., Ruby, R. B., Loughan, S., Luong, M., Kulik, J., Watkins, H. M., Seigerman, M. (2015) Rationalizing meat consumption: The 4Ns. Appetite, 91: 114-128.

Portinga, W., Spence, A., Whitmarsh, L., Capstick, S., and Pidgeon, N. F. (2011) Uncertain climate: An investigation into public scepticism about anthropogenic climate change. Global Environmental Change, 21(3), 1015-1024.

Regan, Á., Shan, L., McConnon, Á., Marcu, A., Raats, M., Wall, P., and Barnett, J. (2014) Strategies for dismissing dietary risks: insights from user-generated comments online. Health, Risk \& Society, 16(4), 308-322.

Rogers, R. A. (2008) Beasts, burgers, and hummers: Meat and the crisis of masculinity in contemporary television advertisements. Environmental Communication, 2(3), 281-301.

Schmidt, A. and Schäfer, M. S. (2015). Constructions of climate justice in German, Indian and US media. Climatic Change, 133(3), 535-549.

Sharman, A. (2014) Mapping the climate sceptical blogosphere. Global Environmental Change, 26, 159-170.

Smith, N. and Joffe, H. (2013) How the public engages with global warming: A social representations approach. Public Understanding of Science, 22(1), 16-32.

Steinfeld, H., Gerber, P., Wassenaar, T., Castel, V., Rosales, M., and de Haan, C. (2006) Livestock's long shadow: Environmental issues and options. Rome: Food and Agriculture Organization of the United Nations.

Swedish Board of Agriculture (2013) Hållbar köttkonsumtion: Vad är det? Hur når vi dit? (Sustainable meat consumption: What is it? How do we get there?) (Report no. 2013:1). Sweden: Jordbruksverket.

Swedish Board of Agriculture (2015) Food consumption and nutritive values, data up to 2015 (Report no. JO 44 SM 1501). Sweden: Jordbruksverket. 
Swyngedouw, E. (2010) Apocalypse forever? Post-political populism and the spectre of climate change. Theory, Culture \& Society, 28(2-3), 214-232.

Tobler, C., Visschers, V. H. M., Siegrist, M. (2011) Eating green: Consumers’ willingness to adopt ecological food consumption behaviors. Appetite, 57, 674-682.

Tracy, S. J. (2010) Qualitative quality: Eight "big-tent” criteria for excellent qualitative research. Qualitative Inquiry, 16(10), 837-851.

Vi-Skogen (2017) Varmare klimat - iskall nyhet (Warmer climate - ice cold news). Retrieved from: https://viskogen.se/nyhet/ny-rapport-klimatskeptikerna-gor-comeback/.

Wibeck, V. (2014) Social representations of climate change in Swedish lay focus groups: Local or distant, gradual or catastrophic. Public Understanding of Science, 23(2), 204-219.

Williams, H. T. P., McMurray, J. R., Kurz, T., and Lambert F. H. (2015) Network analysis reveals open forums and echo chambers in social media discussions of climate change. Global Environmental Change, 32, 126-138.

\footnotetext{
${ }^{1}$ One was an Op-Ed article and the other was a report on that article.

${ }^{2}$ Discursive strategies should here be interpreted as “forms of (discursive) manipulation of 'reality' by social actors in order to achieve a certain goal. ... The intervention and its aim can be more or less consciously pursued" (Carvalho, 2005: 3).

${ }^{3}$ According to its editor-in-chief, Land is the only newspaper "with a focus on modern life outside the big cities.” http://www.lrfmedia.se/sv/titles/land, retrieved 9 June 2017.

${ }^{4}$ Available at https://www.facebook.com/abdebatt/posts/1761811180749421, retrieved 9 June 2017.

${ }^{5}$ Available at https://www.facebook.com/land/posts/1372909122753420, retrieved 9 June 2017.

${ }^{6}$ Possibly, this was the second time the article was shared on Land's Facebook page. The first time was not available when the comments were downloaded for analysis.

${ }^{7}$ Facebook comments were translated from Swedish by a professional translator.

${ }^{8}$ The title of this article derives from this quote.

${ }^{9}$ The song “Öppna Landskap” was written by Ulf Lundell.
} 